\title{
Antitumor activity of dobutamine on human osteosarcoma cells
}

\author{
JUN YIN $^{1,2}$, QIRONG DONG ${ }^{1}$, MINQIAN ZHENG ${ }^{2}$, XIAOZU XU ${ }^{2}$, \\ GUOYOU ZOU ${ }^{2}$, GUOLIN MA ${ }^{3}$ and KEFENG $\mathrm{LI}^{4,5}$ \\ ${ }^{1}$ Department of Orthopedics, Second Affiliated Hospital of Soochow University, Suzhou, Jiangsu 215004; \\ ${ }^{2}$ Department of Orthopedics, First People's Hospital of Yancheng, Yancheng, Jiangsu 224006; ${ }^{3}$ Department of Radiology, \\ China-Japan Friendship Hospital, Beijing 100029, P.R. China; ${ }^{4}$ School of Medicine, University of California, \\ San Diego, CA 92103, USA; ${ }^{5}$ Tianjin Sunnypeak Biotech Co., Ltd., Tianjin 300457, P.R. China
}

Received March 28, 2015; Accepted March 8, 2016

DOI: $10.3892 / 01.2016 .4479$

\begin{abstract}
Dobutamine has been widely used for the treatment of heart failure and cardiogenic shock since the 1970s. Osteosarcoma is the most commonly observed malignant bone tumor in children. Currently, there are no effective drugs for the treatment of osteosarcoma. In the present study, the potential anticancer activity of dobutamine on human osteosarcoma cells was examined. Human osteosarcoma MG-63 cells were treated with dobutamine at various concentrations and for various incubation times. The inhibition of cell growth by dobutamine was determined by 3-(4,5-dimethylthiazol-2-yl)-2,5-diphenyltetrazolium bromide assay. Flow cytometry was utilized to evaluate the effect of dobutamine on cell apoptosis and the cell cycle. Furthermore, the expression levels of caspase- 3 and caspase- 9 were assessed by western blot analysis. The influence of dobutamine on cancer cell migration and invasion was additionally evaluated using wound-healing assay and the Boyden Chamber migration method. Dobutamine significantly inhibited the growth of MG-63 cells at a concentration of $10 \mu \mathrm{M}$ or higher when incubated for $12 \mathrm{~h}$ or longer $(\mathrm{P}=0.023)$. Dobutamine augmented cell apoptosis and arrested the cell cycle in the G2/M phase. Western blot analysis revealed that dobutamine induces expression of caspase-3 and caspase-9. In addition, the invasiveness and migration of MG-63 cells was inhibited by dobutamine in a concentration-dependent manner. The results of the present study may lead to novel applications for dobutamine in the treatment of osteosarcoma.
\end{abstract}

Correspondence to: Dr Qirong Dong, Department of Orthopedics, Second Affiliated Hospital of Soochow University, 1055 Sanxiang Road, Suzhou, Jiangsu 215004, P.R. China

E-mail: dqr_szu@163.com

Dr Guolin Ma, Department of Radiology, China-Japan Friendship Hospital, 2 Yinghua Dongjie, Beijing 100029, P.R. China

E-mail: maguolin1007@qq.com

Key words: osteosarcoma, dobutamine, anticancer activity

\section{Introduction}

Osteosarcoma is the most commonly observed primary malignant cancer of the bone in children, and possesses high incidence and mortality rates (1). The tumor predominantly arises from the metaphyses of the long bones with active bone growth and repairation, such as the knee joint, lower femur and upper tibia. As osteosarcoma is considered to be a radioresistant tumor, chemotherapy is the primary approach for the treatment of osteosarcoma (2). However, the currently utilized chemotherapy regimens demonstrate low efficacy for the treatment of this tumor (3). Current chemotherapeutic drugs, including ifosfamide, cisplatin and high-dose methotrexate, have a number of side-effects and their use may result in acquired drug resistance in osteosarcoma cells (4). Furthermore, the prognosis of osteosarcoma is poor and $>30 \%$ of patients succumb to pulmonary metastases within 5 years of diagnosis (5). Therefore, there is an urgent requirement for the development of novel effective therapeutic drugs for the treatment of osteosarcoma.

Yes-associated protein (YAP), a transcriptional co-activator, is a key regulator of the Hippo signaling pathway (6). When YAP is recruited to the nucleus, transcription of cell proliferation-promoting and anti-apoptotic genes is continuously activated $(7,8)$. High expression of YAP has been observed in a number of types of tumor, including osteosarcoma, hepatocellular, colorectal, ovarian, breast and lung cancer cases, as well as gastric carcinoma, and has been reported to be correlated with a poor prognosis (9-12). These findings suggest that YAP may contribute to a malignant cellular phenotype and therefore may be an important target for anticancer drugs (13).

Dobutamine is a synthetic catecholamine developed by Eli Lilly and Company in the 1970s (14). It has been widely used as an inotropic drug for hemodynamic support in the treatment of congestive heart failure, as well as cardiogenic and septic shock (15). A previous study demonstrated that dobutamine is able to attenuate YAP-dependent transcription by inhibiting its nuclear translocation (16).

In the present study, the effect of dobutamine on the proliferation, apoptosis and invasiveness of the MG-63 human osteosarcoma cell line was investigated. The results of the present study demonstrated the potential effectiveness of dobutamine for the treatment of osteosarcoma. 
Table I. Cell cycle phase distribution and apoptosis of MG-63 cells.

\begin{tabular}{lcccc}
\hline & \multicolumn{4}{c}{ Cell cycle phase } \\
\cline { 2 - 4 } Group & $\mathrm{G} 0 / \mathrm{G} 1$ & $\mathrm{~S}$ & $\mathrm{G} 2 / \mathrm{M}$ & \\
\hline Control & $54.12 \pm 6.53$ & $25.60 \pm 5.33$ & $20.28 \pm 1.79$ & \\
$1 \mu \mathrm{M}$ dobutamine & $55.19 \pm 3.16$ & $25.37 \pm 3.66$ & $19.44 \pm 5.01$ & $2.2 \pm 0.4$ \\
$5 \mu \mathrm{M}$ dobutamine & $53.96 \pm 4.58$ & $23.18 \pm 6.34$ & $22.86 \pm 4.27$ & $2.9 \pm 1.7$ \\
$10 \mu \mathrm{M}$ dobutamine & $49.82 \pm 2.99$ & $26.78 \pm 5.92$ & $23.40 \pm 6.52$ & $7.0 \pm 2.5^{\mathrm{a}}$ \\
$25 \mu \mathrm{M}$ dobutamine & $50.62 \pm 5.27$ & $21.50 \pm 4.59$ & $27.88 \pm 4.55^{\mathrm{b}}$ & $11.6 \pm 4.7^{\mathrm{c}}$ \\
$50 \mu \mathrm{M}$ dobutamine & $51.21 \pm 6.52$ & $18.39 \pm 2.79$ & $30.40 \pm 7.26^{\mathrm{d}}$ & $13.2 \pm 1.8^{\mathrm{e}}$ \\
\hline
\end{tabular}

${ }^{\mathrm{a}} \mathrm{P}=0.012,{ }^{\mathrm{b}} \mathrm{P}=0.007,{ }^{\mathrm{c}} \mathrm{P}=0.020,{ }^{\mathrm{d}} \mathrm{P}=0.003$ and ${ }^{\mathrm{e}} \mathrm{P}=0.026$ vs. control group.

\section{Materials and methods}

The MG-63 human osteosarcoma cell line was purchased from the Shanghai Cell Bank of the Chinese Academy of Sciences (Shanghai, China). Dulbecco's Modified Eagle's Medium (DMEM) and fetal bovine serum (FBS) were obtained from GE Healthcare Life Sciences (Logan, UT, USA). Propidium iodide (PI) and dobutamine were obtained from Sigma-Aldrich (St. Louis, MO, USA). The Annexin V-fluorescein isothiocyanate (FITC) apoptosis detection kit was obtained from Beckman Coulter, Inc. (Brea, CA, USA).

Cell culture. MG-63 cells were grown in medium at $37^{\circ} \mathrm{C}$ in an atmosphere with $5 \% \mathrm{CO}_{2}$. Culture medium supplemented with $10 \%$ FBS, $100 \mathrm{U} / \mathrm{ml}$ penicillin (Gibco; Thermo Fisher Scientific Inc., Waltham, MA, USA), $100 \mu \mathrm{g} / \mathrm{ml}$ streptomycin (Gibco; Thermo Fisher Scientific Inc.) and DMEM was used for MG-63 culture.

3-(4,5-dimethylthiazol-2-yl)-2,5-diphenyltetrazolium bromide (MTT) assay. The influence of dobutamine treatment on cell viability was determined using an MTT assay. Cells were seeded into a 96-well plate (Corning, New York, NY, USA) overnight at $37^{\circ} \mathrm{C}$ and incubated with various concentrations of dobutamine $(1,5,10,25$ and $50 \mu \mathrm{M})$ for $12,24,48$ and $72 \mathrm{~h}$. Following the indicated treatments, the cells were incubated with MTT $(0.25 \mathrm{mg} / \mathrm{ml}$; Sigma-Aldrich) in phosphate-buffered saline (PBS; Gibco; Thermo Fisher Scientific Inc.) for $4 \mathrm{~h}$ at $37^{\circ} \mathrm{C}$, followed by removal of the medium and addition of $1 \mathrm{ml} \mathrm{100 \%} \mathrm{dimethyl} \mathrm{sulfoxide} \mathrm{(Beyotime} \mathrm{Institute} \mathrm{of} \mathrm{Biotech-}$ nology, Shanghai, China) to solubilize the MTT-formazan product. The absorbance at $490 \mathrm{~nm}$ was determined using an automatic multi-well spectrophotometer (Bio-Rad Laboratories, Inc., Hercules, CA, USA). The inhibitory rate of cell growth was calculated as [1-treatment group/control group)] $\mathrm{x} 100$. The growth curve was drawn using time as the abscissa and inhibition rate as the ordinate. Each dobutamine dose was used in triplicate, and the MTT assay was repeated at least twice.

Flow cytometric analysis. The rate of apoptosis and percentage of cells in G1, S and G2/M phases was measured by flow cytometry. Following treatment of the experimental

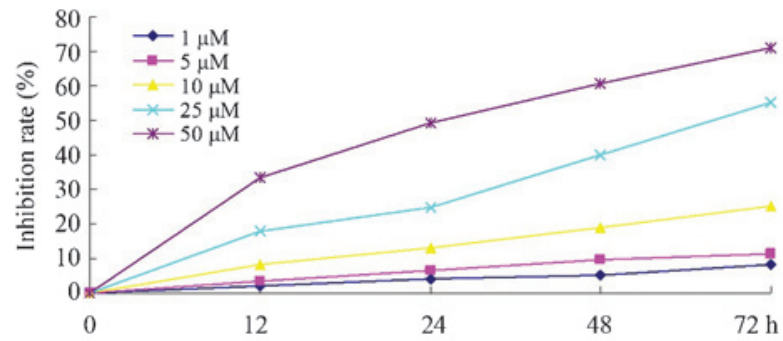

Figure 1. Effect of dobutamine treatment on the proliferation of MG-63 cells. Cells were treated with various concentrations $(1,5,10,25$ and $30 \mu \mathrm{M})$ of dobutamine for $12,24,48$ and $72 \mathrm{~h}$. The inhibition rate (\%) of dobutamine was calculated using the following formula: [1-treatment group/control group)] $\mathbf{x} 100 \%$

groups in MTT for $24 \mathrm{~h}$, cells were harvested, trypsinized, washed twice with PBS and resuspended in binding buffer (Beyotime Institute of Biotechnology). The cells were subsequently stained with Annexin V-FITC and PI according to the manufacturer's protocol and analyzed by flow cytometry. The cell suspension was incubated with $50 \mu \mathrm{g} / \mathrm{ml}$ PI solution and $50 \mathrm{U} / \mathrm{ml}$ RNase (Beyotime Institute of Biotechnology) for 30 min in order to observe the cell cycle stage. Flow cytometric analysis was performed on a BD FACSCaliber ${ }^{\mathrm{TM}}$ using CellQuest software, version 5.1 (BD Biosciences, Franklin Lakes, NJ, USA).

Cell invasion analysis. The effect of treatment with dobutamine on the invasion of MG-63 cells was investigated using Transwell chambers with polycarbonate filters (pore size of $8 \mu \mathrm{m}$; Beyotime Institute of Biotechnology). MG-63 cells were seeded into the upper chamber at a density of $1 \times 10^{5}$ cells $/ \mathrm{ml}$ and incubated in $0.6 \mathrm{ml}$ DMEM medium containing $10 \% \mathrm{FBS}$ and various concentrations $(1,5,10,25$ and $50 \mu \mathrm{M})$ of dobutamine. The lower chamber was filled with $0.6 \mathrm{ml}$ DMEM medium containing 20\% FBS. Following $24 \mathrm{~h}$ of incubation at $37^{\circ} \mathrm{C}$, cells on the upper filter that had not migrated through were removed by wiping, and the remaining cells were fixed in $4 \%$ paraformaldehyde (Beyotime Institute of Biotechnology) for a total of $1 \mathrm{~h}$. Cells that had migrated through the filter were stained using hematoxylin (Beyotime Institute of Biotechnology) and visualized and counted under a microscope (Olympus IX53; Olympus, Tokyo, Japan). 


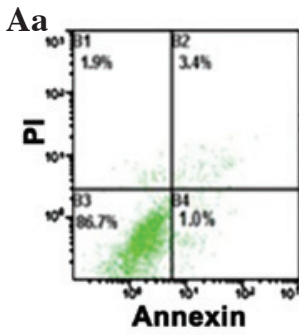

Ba
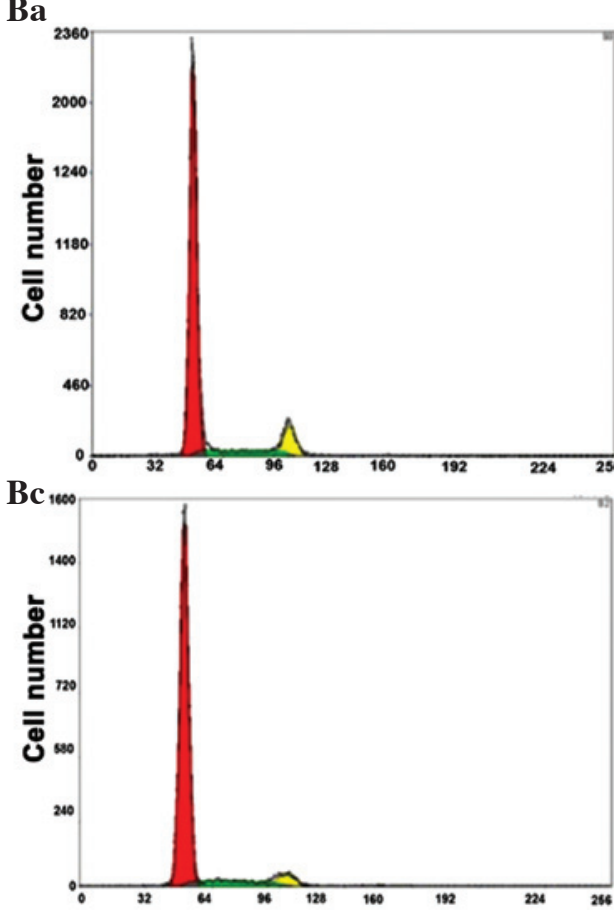
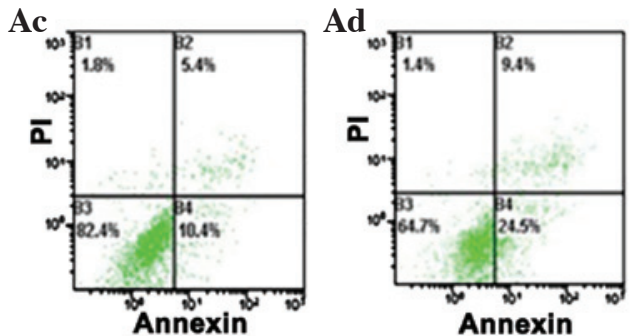

Bb
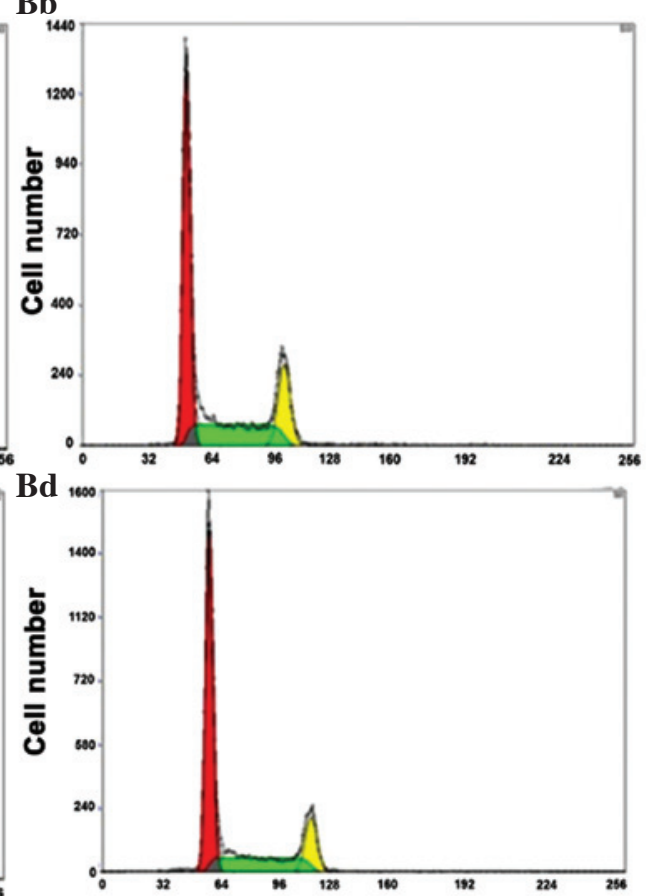

Figure 2. (A) Cell cycle and (B) apoptosis distribution of MG-63 cells in response to dobutamine treatment: (a) Control, (b) $10 \mu \mathrm{M}$ dobutamine, (c) $25 \mu \mathrm{M}$ dobutamine and (d) $50 \mu \mathrm{M}$ dobutamine. Data are presented as the mean \pm standard deviation $(\mathrm{n}=6) .{ }^{*} \mathrm{P}<0.05$ compared with the control group.

Western blot analysis. The present study examined the levels of protein expression of caspase-3 and caspase-9 in MG-63 cells prior to and following treatment with dobutamine. The cells were treated with the different concentrations of dobutamine $(1,5,10,25$ and $50 \mu \mathrm{M})$. The cells were then harvested in $5 \mathrm{ml}$ of medium, pelleted by centrifugation $(1,000 \mathrm{x} \mathrm{g}$ for $5 \mathrm{~min}$ at $4^{\circ} \mathrm{C}$ ), washed twice using ice-cold PBS and lysed in ice-cold HEPES buffer (50 mmol/l; pH7.5), $10 \mathrm{mmol} / \mathrm{l} \mathrm{NaCl}$, $5 \mathrm{mmol} / 1 \mathrm{MgCl}_{2}, 1 \mathrm{mmol} / 1$ ethylenediaminetetraacetic acid (all Beyotime Institute of Biotechnology), 110\% glycerol (v/v), $1 \%$ Triton X-100 (v/v 1X complete), a cocktail of SigmaFast protease inhibitors (1X complete; Sigma-Aldrich), followed by treatment with $1 \mathrm{mg} / \mathrm{l}$ dobutamine on ice for $30 \mathrm{~min}$. The cell lysates were clarified by centrifugation $(15,000 \mathrm{x}$ g for $10 \mathrm{~min}$ at $4^{\circ} \mathrm{C}$ ), and the supernatants were analyzed immediately or stored at $-80^{\circ} \mathrm{C}$ until required. Equivalent quantities of protein $(50 \mu \mathrm{g})$ from total cell lysates were resolved by sodium dodecyl sulfate polyacrylamide gel electrophoresis using precast $12 \%$ BIS-TRIS gradient gels and transferred onto polyvinylidene difluoride membranes. Membranes were blocked overnight at $4^{\circ} \mathrm{C}$ using blocking buffer [5\% skimmed dried milk (v/v), $150 \mathrm{mmol} / 1 \mathrm{NACl}, 10 \mathrm{mmol} / \mathrm{l}$ Tris ( $\mathrm{pH} 8.0)$ and $0.05 \%$ Tween $20(\mathrm{v} / \mathrm{v})$; Beyotime Institute of Biotechnology]. Proteins were detected by incubation in blocking buffer overnight at $4^{\circ} \mathrm{C}$ with the following primary antibodies: Mouse

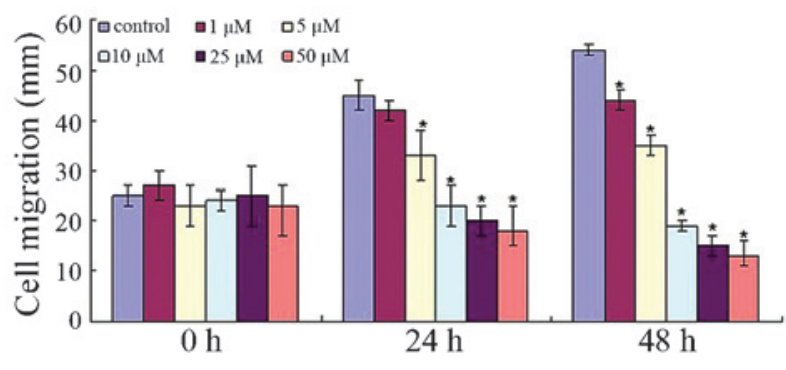

Figure 3. Effect of dobutamine treatment on the migration of MG-63 cells. Data are presented as the mean \pm standard deviation $(n=6) .{ }^{*} \mathrm{P}<0.05$ compared with the control group.

anti-human monoclonal caspase-3 antibody (1:10,00 dilution; sc-65496), mouse anti-human monoclonal caspase-9 antibody (1:10,00 dilution; sc-56073) and mouse anti-human monoclonal GADPH antibody (1:10,00 dilution; sc-47778) (all Santa Cruz Biotechnology, Inc, Dallas, TX, USA). Unbound antibody was removed by washing with Tris-buffered saline (pH7.2) containing 0.5\% Tween 20 (TBS-T; Beyotime Institute of Biotechnology). The membrane was subsequently incubated at room temperature with horseradish peroxidase-conjugated secondary antibody. Subsequent to washing with TBS-T three times, bands were visualized by enhanced chemiluminescence 

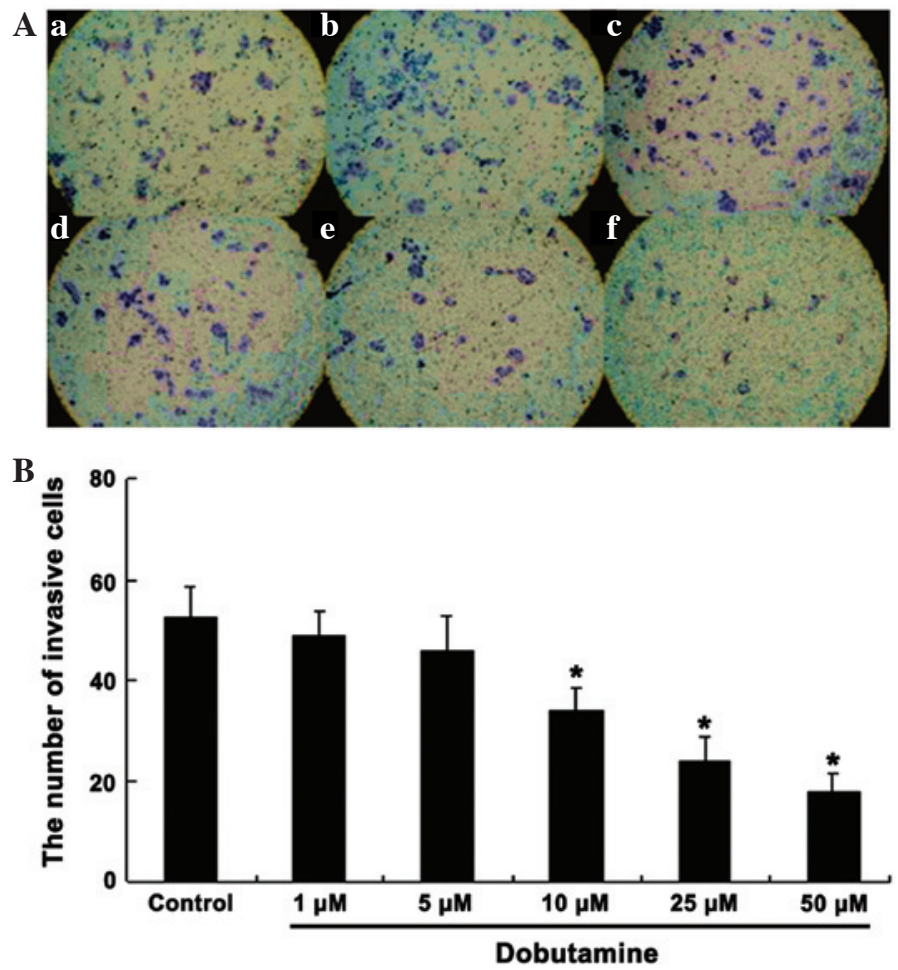

Figure 4. Effect of dobutamine treatment on MG-63 cell invasiveness. (A) Cells were treated with the following concentrations of dobutamine for 24 h: (a) Control, (b) $1 \mu \mathrm{M}$, (c) $5 \mu \mathrm{M}$, (d) $10 \mu \mathrm{M}$, (e) $25 \mu \mathrm{M}$ and (f) $50 \mu \mathrm{M}$. (B) Number of invasive MG-63 cells following dobutamine treatment for $24 \mathrm{~h}$. Data are presented as the mean \pm standard deviation $(\mathrm{n}=6)$. ${ }^{*} \mathrm{P}<0.05$ compared with the control group.

system (Pierce Biotechnology, Rockford, IL, USA), and the protein intensities were quantified using AlphaEaseFC 4.1.0 software (Alpha Innotech, San Leandro, CA, USA).

Statistical analysis. Statistical analyses were performed using SPSS version 15.0 (SPSS Inc., Chicago, IL, USA). Comparisons between two samples (experimental and control group) were employed by Student's t-test. $\mathrm{P}<0.05$ was considered to represent a statistically significant difference.

\section{Results and Discussion}

Dobutamine inhibits the proliferation of $M G$ - 63 osteosarcoma cells. The results of the present study revealed that dobutamine significantly inhibited cell proliferation in a time- and concentration-dependent manner compared with the control group. As demonstrated by the proliferation inhibition graph (Fig. 1), treatment with 10,25 and $50 \mu \mathrm{M}$ dobutamine had a significant inhibitory effect on the survival of MG-63 cells $(\mathrm{P}=0.032)$.

Dobutamine augments cell apoptosis and arrests the cell cycle. Annexin V/PI staining was used to measure dobutamine-induced apoptosis. Compared with the control group, dobutamine induced a significant increase in apoptotic death, following pretreatment of MG-63 cells with 5, 10, 25 and $50 \mu \mathrm{M}$ for $24 \mathrm{~h}(\mathrm{P}=0.028$; Table $\mathrm{I})$. The percentage of MG-63 cells in G2/M phases was significantly increased at dobutamine concentrations of 25 and $50 \mu \mathrm{M}(\mathrm{P}=0.007$ and $\mathrm{P}=0.003$, respectively), and the percentage of cells in S-phase was significantly decreased $(\mathrm{P}=0.039)$ compared with the control group (Fig. 2).

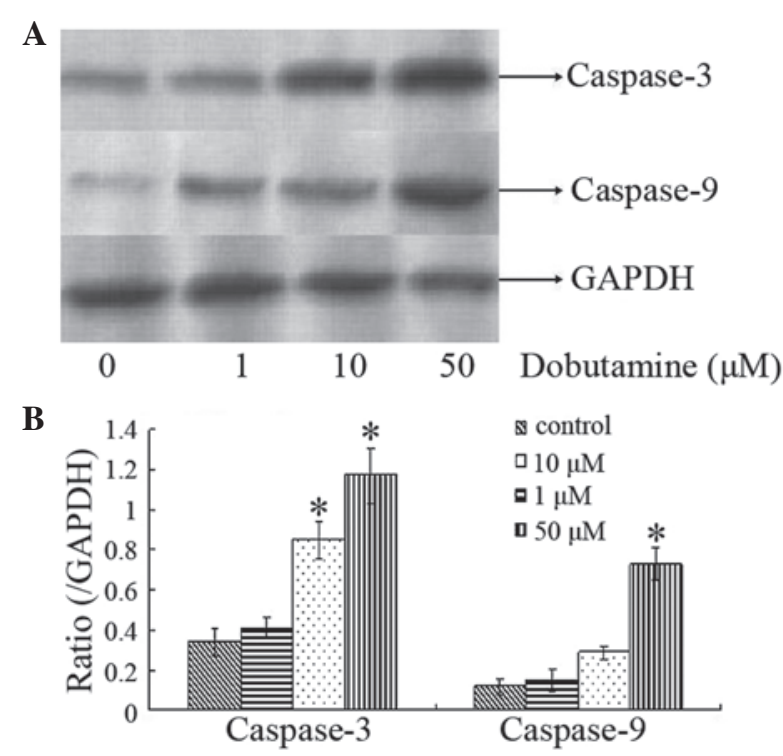

Figure 5. Effect of dobutamine treatment on protein expression of caspase-3 and caspase-9 in MG-63 cells. (A) Western blot analysis and (B) quantification of protein expression of caspase-3 and caspase-9. Cells were treated with various concentrations of dobutamine $(0,1,10$ and $50 \mu \mathrm{M})$ for $72 \mathrm{~h}$. GAPDH was used as an internal control gene. The expression level was calculated as the ratio of caspase-3 or caspase-9:GAPDH. Data are presented as the mean \pm standard deviation $(n=6) .{ }^{*} \mathrm{P}<0.05$ compared with the control group. GAPDH, glyceraldehyde-3-phosphate dehydrogenase.

Dobutamine reduces the migration and invasion of $M G-63$ cells. To investigate whether dobutamine treatment affects osteosarcoma cell movement, the migratory rate of the MG-63 cells was observed.Fig. 3 demonstrates that dobutamine 
significantly decreased cell migration from the edge of the wound $(\mathrm{P}=0.041)$. Similarly, the cell invasion/Transwell assay showed that a large number of cells passed through the filter in the control group, whereas the cells passing through the filter were markedly reduced following dobutamine treatment. Furthermore, treatment with dobutamine reduced the number of invasive cells in a concentration-dependent manner (Fig. 4). The number of invasive cells in the dobutamine groups was significantly reduced compared with that in the control group $(\mathrm{P}=0.039$ for $10 \mu \mathrm{M}, \mathrm{P}=0.015$ for $25 \mu \mathrm{M}$ and $\mathrm{P}=0.011$ for $50 \mu \mathrm{M})$ (Fig. 4).

Dobutamine induces expression of caspase- 3 and caspase-9. Caspases are a family of endoproteases that provide crucial links in cell regulatory networks that control inflammation and cell death (17). Caspase-3 and 9 are crucial mediators in apoptosis signaling pathways (18). Western blot analysis was used to investigate the expression of caspase- 3 and caspase-9 in MG-63 cells following dobutamine treatment. Protein expression analysis indicated that caspase- 3 levels were increased following treatment with dobutamine at the concentrations of 10 and $50 \mu \mathrm{M}$ for $72 \mathrm{~h}(\mathrm{P}=0.011$ and $\mathrm{P}=0.013$, respectively), and caspase- 9 levels were increased following treatment with dobutamine at a concentration of $50 \mu \mathrm{M}$ for $72 \mathrm{~h}(\mathrm{P}=0.031)$ (Fig. 5). These findings indicated that dobutamine may induce cancer cell apoptosis and cell death.

Recent reports have demonstrated that YAP is highly expressed in human osteosarcoma MG-63 cells (19). The results of the present study indicate that the inhibitory effect of dobutamine may be associated with the inhibition of YAP translocation. Silencing of the YAP gene by RNA interference led to a similar effect to that caused by dobutamine (20). In addition, the present study found that dobutamine arrests the cell cycle at the G2/M transition stage and augments cell apoptosis. Previous studies have demonstrated that YAP activates cell apoptosis in response to DNA damage via interaction with p73 in several cancer cell lines (21). The findings of the present study may result in a novel application for dobutamine in the treatment of cancer.

In conclusion, the results of the present study demonstrated that dobutamine was able to significantly suppress osteosarcoma cell growth by inhibiting cell proliferation, inducing cell apoptosis and redistributing cell cycle phases. These findings indicate that dobutamine may become a novel therapeutic agent for the treatment of osteosarcoma. However, additional in vivo studies are required in order to confirm the effectiveness and safety of dobutamine in the treatment of osteosarcoma.

\section{Acknowledgements}

This study was supported by grants from the National Science and Technology Support Program (no. 2012BAI10B02) and the National Science Foundation of China (no. 81571641), and an internal grant from China-Japan Friendship Hospital, Beijing, China (no. 2014-3-MS-18).

\section{References}

1. Basu-Roy U, Basilico C and Mansukhani A: Perspectives on cancer stem cells in osteosarcoma. Cancer Lett 338: 158-167, 2013.

2. Ando K, Heymann MF, Stresing V, Mori K, Rédini F and Heymann D: Current therapeutic strategies and novel approaches in osteosarcoma. Cancers (Basel) 5: 591-616, 2013.

3. Lamplot JD, Denduluri S, Qin J, Li R, Liu X, Zhang H, Chen X, Wang N, Pratt A, Shui W, et al: The current and future therapies for human osteosarcoma. Curr Cancer Ther Rev 9: 55-77, 2013.

4. Luetke A, Meyers PA, Lewis I and Juergens H: Osteosarcoma treatment - where do we stand? A state of the art review. Cancer Treat Rev 40: 523-532, 2014.

5. Loh AH, Navid F, Wang C, Bahrami A, Wu J, Neel MD and Rao BN: Management of local recurrence of pediatric osteosarcoma following limb-sparing surgery. Ann Surg Oncol 21: 1948-1955, 2014

6. Huang J, Wu S, Barrera J, Matthews K and Pan D: The Hippo signaling pathway coordinately regulates cell proliferation and apoptosis by inactivating Yorkie, the Drosophila homolog of YAP. Cell 122: 421-434, 2005.

7. Zhao B, Wei X, Li W, Udan RS, Yang Q, Kim J, Xie J, Ikenoue T, $\mathrm{Yu} \mathrm{J}, \mathrm{Li} \mathrm{L}$, et al: Inactivation of YAP oncoprotein by the Hippo pathway is involved in cell contact inhibition and tissue growth control. Genes Dev 21: 2747-2761, 2007.

8. Steinhardt AA, Gayyed MF, Klein AP, Dong J, Maitra A, Pan D, Montgomery EA and Anders RA: Expression of Yes-associated protein in common solid tumors. Hum Pathol 39: 1582-1589, 2008.

9. Zender L, Spector MS, Xue W, Flemming P, Cordon-Cardo C, Silke J,Fan ST, Luk JM, Wigler M, Hannon GJ, et al: Identification and validation of oncogenes in liver cancer using an integrative oncogenomic approach. Cell 125: 1253-1267, 2006.

10. Overholtzer M, Zhang J, Smolen GA, Muir B, Li W, Sgroi DC, Deng CX, Brugge JS and Haber DA: Transforming properties of YAP, a candidate oncogene on the chromosome 11q22 amplicon. Proc Natl Acad Sci USA 103: 12405-12410, 2006.

11. Roden $\mathrm{R}$ and $\mathrm{Wu}$ TC: How will HPV vaccines affect cervical cancer? Nat Rev Cancer 6: 753-763, 2006.

12. Castle PE, Dockter J, Giachetti C, Garcia FA, McCormick MK, Mitchell AL, Holladay EB and Kolk DP: A cross-sectional study of a prototype carcinogenic human papillomavirus E6/E7 messenger RNA assay for detection of cervical precancer and cancer. Clin Cancer Res 13: 2599-2605, 2007.

13. Molden T, Kraus I, Karlsen F, Skomedal H and Hagmar B: Human papillomavirus E6/E7 mRNA expression in women younger than 30 years of age. Gynecol Oncol 100: 95-100, 2006.

14. Tuttle RR and Mills J: Dobutamine: Development of a new catecholamine to selectively increase cardiac contractility. Circ Res 36: 185-196, 1975.

15. Roesslein M, Froehlich C, Jans F, Piegeler T, Goebel U and Loop T: Dobutamine mediates cytoprotection by induction of heat shock protein 70 in vitro. Life Sci 98: 88-95, 2014.

16. Bao $Y$, Nakagawa $K$, Yang $Z$, Ikeda $M$, Withanage $K$, Ishigami-Yuasa M, Okuno Y, Hata S, Nishina H and Hata Y: A cell-based assay to screen stimulators of the Hippo pathway reveals the inhibitory effect of dobutamine on the YAP-dependent gene transcription. J Biochem 150: 199-208, 2011.

17. Brentnall M, Rodriguez-Menocal L, De Guevara RL, Cepero E and Boise LH: Caspase-9, caspase-3 and caspase-7 have distinct roles during intrinsic apoptosis. BMC Cell Biol 14: 32, 2013.

18. Fujita E, Egashira J, Urase K, Kuida K and Momoi T: Caspase-9 processing by caspase-3 via a feedback amplification loop in vivo. Cell Death Differ 8: 335-344, 2001.

19. Zhang YH, Li B, Shen L, Shen Y and Chen XD: The role and clinical significance of YES-associated protein 1 in human osteosarcoma. Int J Immunopathol Pharmacol 26: 157-167, 2013.

20. Zhou Z, Zhu JS and Xu ZP: RNA interference mediated YAP gene silencing inhibits invasion and metastasis of human gastric cancer cell line SGC-7901. Hepatogastroenterology 58: 2156-2161, 2011.

21. Lapi E, Di Agostino S, Donzelli S, Gal H, Domany E, Rechavi G, Pandolfi PP, Givol D, Strano S, Lu X and Blandino G: PML, YAP, and $\mathrm{p} 73$ are components of a proapoptotic autoregulatory feedback loop. Mol Cell 32: 803-814, 2008. 